\title{
The Political Offenders in the Misamis Oriental Provincial Jail: A Basis for Prevention and Suppression Strategies of Its Local Governments
}

\author{
ERWIN B. BUCIO \\ ORCID No. 0000-0002-0012-704X \\ erwinbucio@yahoo.com.ph \\ Liceo de Cagayan University \\ Cagayan de Oro City, Philippines \\ LEMUEL C. EDROLIN \\ ORCID No. 0000-0001-7994-5813 \\ edrolinl.liceo@gmail.com \\ Liceo de Cagayan University \\ Cagayan de Oro City, Philippines
}

\begin{abstract}
This study determined the causes of political crimes committed in Misamis Oriental to draw suggestions on preventing and suppressing political crimes. The respondents were the political offenders detained in Misamis Oriental Provincial Jail. This descriptive research used an interview schedule for data gathering. Findings reveal that the majority of the offenders had a big family, earning as farmers a very minimal income, lacked education, and strongly adhered to the principles of equality and justice. The main cause of political crimes in Misamis Oriental was social inequality and injustice. Political crimes in Misamis Oriental can be prevented by establishing priority and sustainable programs for poverty alleviation and promotion and protection of human rights.
\end{abstract}


Keywords: political offenders, crime prevention and suppression strategies, Misamis Oriental Provincial Jail, local government

\section{INTRODUCTION}

In a democratic society, everyone has the right to express one's grievances and dissatisfaction against the government. Everyone has the opportunity to exercise his or her political beliefs and aspirations free from any government interventions. However, the same should be enjoyed within the ambit of the law; otherwise, the exercise of said rights would qualify into a crime. Social, political, or economic issues that are neglected or are addressed by the government but are viewed by the concerned people with dissatisfaction may give rise to the commission of political offenses.

In history, if Justice Holmes were correct, the political offense would remain the oldest and the most important criminal phenomenon in human society (Philippine Law Journal 395, 1981). The king of Egypt and Hittite had entered into an agreement for the mutual surrender of political offenders, and it was recorded as one of the earliest treaties concluded in the $13^{\text {th }}$ century. For being annoying to higher authorities, political offenders were severely repressed in the early history. Moreover, the Romans who were guilty of crime majestatis were given corporal punishment or to banishment, and even their descendants could even be punished (Harvard Research on International Law as cited in the Philippine Law journal, 1981).

Political crime is any offense involving overt acts or omissions that prejudice the fundamental interest of the state, its government or the political system while the persons who committed the same are classified as political offenders. According to the Supreme Court of the Philippines, political crimes are those directly aimed against the political order as well as such common crimes as may be committed to achieving a political purpose" (People vs. Hernandez, 99 Phil. Reports 155, 1956).

There are two kinds of political offenders, namely pure and relative. Pure political offenders are those whose actions are geared towards violation of political order of the state including its independence, territorial integrity, forms of its government, their mutual relations and organization of public powers and violations of political rights of citizens. The crimes of espionage, rebellion, treason, sedition are pure political offenses. On the other hand, relative political offenders are those who commit common crimes that have connections with 
political grounds, or have tied with the consummation of political struggles (Cantrell, 1997)

The Philippine government, under its police power, enacted laws to define and prosecute individual or group actions constituting political offenses. The government has also initiated the "Balik Baril Program" which is spearheaded by the AFP to minimize or eliminate political offenders. Despite of these efforts, the researchers have gathered from the web that there are 385 political offenders detained in the different jails nationwide, all of them are facing criminal charges. Among them, 19 are elderly, 30 are women, and 49 are suffering from various illnesses.

Provincial jails are managed and operated by the provincial government having territorial jurisdiction over them. Pursuant to RA 6975, provincial jails are mandated to provide for an effective custody and safekeeping of provincial prisoners, any fugitive from justice or person's detained, awaiting for investigation or trial or transfer to national penitentiary. They also take charge of detaining any violent and mentally ill individual who endangers himself or threatens the safety of others.

The Misamis Oriental Provincial Jail (MOPJ) is the recipient of all apprehended offenders within its jurisdiction. It is located at Apolinario-Luna Street, Cagayan de Oro City. The Province of Misamis Oriental for many years has been confronted and disturbed by political insurgents especially in the hinterland Barangays. All political offenders apprehended within the province of Misamis Oriental are now detained in Misamis Oriental Provincial Jail.

In an attempt to present data-based and subject-based crime prevention and suppression strategies, the researchers conceptualized this study.

\section{FRAMEWORK}

This study is based on the assertion advanced by Justice Holmes that the political offense would remain the oldest and the most important criminal phenomenon in human society (Philippine Law Journal 395, 1981). Political offenders are freedom fighters and remain to be such. They are the ones who resisted and fought against oppression, human rights violations, and transgressions of political beliefs and religious principles. They are victims of social injustices and have risked their lives for the protection of the rights of the masses (Ka Fernan, surrendered NPA member).

On the other hand, contrary to Ka Fernan's statement, members of New People's Army (NPA) launched a simultaneous attack in three areas of Bukidnon 
including Del Monte Philippines on February 20, 2013. A security guard and a civilian were killed during their attack while others were wounded. According to the Armed Forces of the Philippines (AFP) spokesman Col. Marcelo Burgos Jr., the said atrocity of NPA is a clear violation of the Comprehensive Agreement on Respect for Human Rights and International Humanitarian Law and Republic Act 985 (Tempo Newspaper, February 21, 2013 Issue).

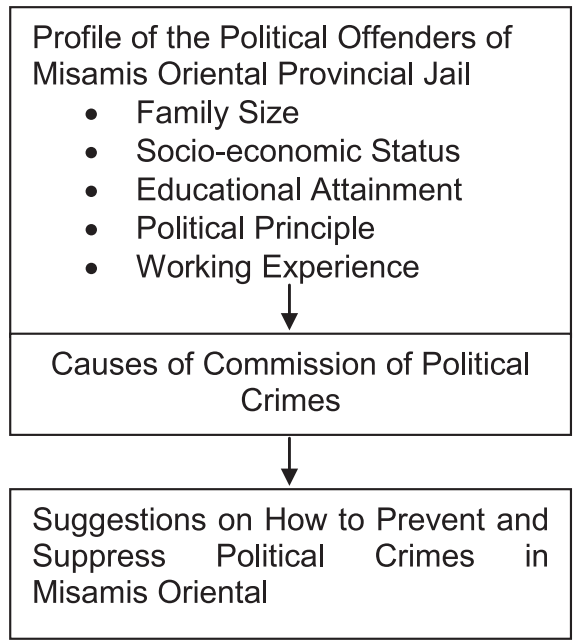

Figure 1. Research Flow of the Study

The socio-economic status of an individual can provide an explanation on how culture, family background, social and economic conditions influence one's identity, values, and overall human development. According to Willem Bonger, "crime is the consequence of economic and social conditions". He emphasized that the result of the capitalistic system, where bourgeois pursued their individual self-interest regardless of consequences just to protect their economic advantage, rejecting altruism, is the flourishing of the commission of crimes. An individual may steal or injure or even kill somebody just to satisfy one's hunger. Hunger may not always mean a lack of food but may also mean a lack of equality, fairness, and justice.

Political offenders are exempted from extradition treaty; part of the said treaty also exempts injurious crime like terrorism. On the other hand, the extradition treaty serves as an important mechanism among nations in combating terrorism. 
There has been an issue on the effectiveness of extradition treaties in combating terrorism. Hence, the United States and the United Kingdom have signed a supplementary treaty excluding violent or injurious crime like terrorism from political offense exemption (Peterson, 1991)

Incarcerated political offenders have been released and, in relation to its former policy of segregation of the non-white population, have it to be a major issue for the series of negotiations in South Africa. The negotiations considered indemnity program among political offenders, but the established legal provisions and political context seem to be in conflict about their implementation. It has been believed that a concrete legal paradigm and confidence in the implementation of the law provide positive effects like clear, definite adherence to its enforcement with public knowledge. On the contrary, the African government indemnity procedures have been politically influenced, partially disregarding the rule of law, causing bitter relationship with the African National Congress one of its primary negotiating party. To this effect, both of them- the African government and the National African Congress have undertaken different moves disregarding legal procedures of releasing the political prisoner (Keightley, 1993).

Political principle refers to a doctrine or conduct of governance believed by an individual or group of individuals to be effective and efficient. Political principles include but not limited to democracy, equality, justice and peace.

The New People's Army, organized by the Communist Party of the PhilippinesNational Democratic Front (CPP-NDF) and classified as political offender under the principles of Marxism-Leninism- Mao Zedong, is still on its revolutionary armed struggles against the government. It demands that the government take extensive consideration of matters concerning land reform, economic stagnation, poverty, and human rights violations.

Section 12 of RA 8551 otherwise known as the "Philippine National Police Reorganization Act of 1998" states that: "The Department of Interior and Local Government shall be relieved of the primary responsibility on matters involving suppression of insurgency and other serious threats to national security. The Philippine National Police shall, through information gathering and performance of its ordinary police functions, support the Armed Forces of the Philippines on matters involving suppression of insurgency, except in cases where the President shall call on the PNP to support the AFP in combat operations".

Crime prevention strategies are those that are adopted by the Police and are designed to eliminate or reduce the opportunity of an individual or group to commit crimes. Crime prevention requires the full cooperation of the 
community as part of participative law enforcement and as indispensable agency where criminal propensities originate. It involves but not limited to reactive patrol as means of police visibility, house-to-house visitations, mingling of patrol force within the community, and most especially the full implementation of the concept of COPS-Community Oriented Policing System.

On the other hand, crime suppression strategies refer to those that are adopted by the police to eliminate the opportunity of an individual or group to commit crimes after having committed the same for the first time. The strategies include the conduct of surveillance and covert operations, apprehension, followup operations, check points, and prosecution of offenders.

The Philippine National Police leadership is intensely focused on crime prevention strategies as evidenced by the remarkable reduction of crime as recorded in the first quarter of the present year as compared to the same period of last year. According to PNP Chief Supt. Agrimero A. Cruz Jr., the decline in the crime rate could be attributed to several programs that include an increase in police visibility and police community partnership, performance and strategic planning, and police integrated patrol system, and localized anti-criminality action plan.

\section{OBJECTIVES OF THE STUDY}

This study aimed at determining the respondents (1) profile in terms of family size, socio-economic status, educational attainment, political principle, and working experience; (2) causes of the commission of political crimes; and (3) suggestions on how to prevent and suppress political crimes in Misamis Oriental.

\section{METHODOLOGY}

The study employed the descriptive research design as it collated, evaluated and interpreted responses to generate a general idea or concept. The respondents were all political offenders or detainees at the Misamis Oriental Provincial Jail. The data were collected through a one-on-one interview using an interview schedule. During the interview, the researchers wore their university ID, formally introduced themselves to the respondents and explained to them the purpose of the research. After obtaining approval from Provincial Governor of Misamis Oriental, the researchers sent a letter asking permission to conduct a study to the Provincial Jail Warden. 


\section{RESULTS AND DISCUSSION}

Table 1 presents the distribution of the respondents by their profile. Majority of the offenders ( 8 or $53.33 \%$ ) had 6 to 10 siblings, while very few ( 2 or $13.33 \%$ ) had 11 to 15 siblings. As to socio-economic status, majority of the offenders (13 or $86.66 \%$ ) had family income of 5 thousand to 10 thousand pesos per month while very few had ( 2 or $13.33 \%$ ) family income of 10 to 20 thousand pesos per month. As to, educational attainment, majority of the offenders (7 or 46.66\%) reached elementary level while few (3 or 20\%) reached college. About political principles, majority (13 or $86.66 \%$ ) chose equality and justice as their political principle. As to working experience, majority of the respondents (8 or $53.33 \%$ ) previously worked as farmers. The rest worked in a private sector, government sector, and as businessman (buy and sell).

Table 1. Distribution of the Profile of the Respondents

\begin{tabular}{|c|c|c|}
\hline Family (Number of Siblings) & Frequency & Percent \\
\hline $1-5$ & 5 & 33.33 \\
\hline $6-10$ & 8 & 53.33 \\
\hline $11-15$ & 2 & 13.33 \\
\hline Total & 15 & 100 \\
\hline Socio-Economic Status (Monthly Income) & & \\
\hline $5,000-10,000$ & 13 & 86.66 \\
\hline $20,000-30,000$ & 2 & 13.33 \\
\hline 30,000 and above & 0 & 0 \\
\hline Total & 15 & 100 \\
\hline Highest Educational Attainment & & \\
\hline Elementary level & 7 & 46.66 \\
\hline High School Graduate & 5 & 33.33 \\
\hline College Level & 3 & 20 \\
\hline College Graduate & 0 & 0 \\
\hline Masteral & 0 & 0 \\
\hline Doctorate & 0 & 0 \\
\hline Total & 15 & 100 \\
\hline
\end{tabular}




\begin{tabular}{|c|c|c|}
\hline \multicolumn{3}{|l|}{ Working Experience } \\
\hline $\begin{array}{l}\text { Private Sector } \\
\text { Buy and sell }\end{array}$ & 1 & 6.66 \\
\hline Government Sector & 1 & 6.66 \\
\hline Farmer & 8 & 53.33 \\
\hline No Works & 4 & 26.66 \\
\hline Total & 15 & 100 \\
\hline \multicolumn{3}{|l|}{ Political Principles } \\
\hline Democracy & 1 & 6.66 \\
\hline Equality & 13 & 86.66 \\
\hline Justice & 13 & 86.66 \\
\hline Peace & 1 & 6.66 \\
\hline Economy & 0 & 0 \\
\hline Others please Specify & 0 & 0 \\
\hline Total & 15 & 100 \\
\hline
\end{tabular}

Table 2 presents the causes of political crimes in Misamis Oriental. Among the causes, social inequality ranked first. Revenge, government abuses or injustices, poverty, and social injustice were second in rank. Social inequality, as referred to by the respondents, consists of inequality in socio-economic status or the gap between the rich and the poor and inequality in giving respect for an individual's human rights. No respect for human rights may lead to revenge against or resentment to the government or to the ruling class in society

Table 2. Summarized Data on the Causes of Political Crimes Committed in Misamis Oriental

\begin{tabular}{|l|c|c|}
\hline \multicolumn{1}{|c|}{ Causes } & Frequency & Rank \\
\hline Social inequality & 6 & 1 \\
\hline Revenge & 4 & 2.5 \\
\hline Government abuses or injustices & 4 & 2.5 \\
\hline Poverty & 4 & 2.5 \\
\hline Social injustice & 4 & 2.5 \\
\hline NPA leaders promised him salary & 3 & 3 \\
\hline Unjust distribution of land by the DAR & 2 & 4.5 \\
\hline
\end{tabular}




\begin{tabular}{|l|l|l|}
\hline Martial law & 2 & 4.5 \\
\hline Enticed because of the issuance of a firearm & 2 & 4.5 \\
\hline $\begin{array}{l}\text { Our system of government is imperialism, feudalism, } \\
\text { and bureaucratic capitalism }\end{array}$ & 1 & 5.5 \\
\hline False accusation against him & 1 & 5.5 \\
\hline For people to enjoy genuine freedom & 1 & 5.5 \\
\hline To fight for social change & 1 & 5.5 \\
\hline
\end{tabular}

\section{Respondent 1}

He cited three reasons for committing political crimes. First, the military burned his house during a combat operation (Gisunog sa mga military ang akong balay). Second, he wanted to avenge the military officers' slaughtering of his domesticated animals for consumption (isip akong balos sa ila kay ilang gipangihaw ang akong mga hayop).Third, he wanted the government to know that he was not happy of the government's abuses. (Para mabibaw-an sa gobyerno nga wala mi nahimout sa ilang pagpang-abuso).

\section{Respondent 2}

He had two reasons for committing political crimes. First, he witnessed the government's unjust governance over its people.(Nakita nako ang dili makaangayon nga pagdala sa gobyerno sa iyang mga tao). Second, poverty enticed him to be part of the group since the NPA leaders promised him a salary (Tungod sa among kalisod naagni ko ug tampo sanglit ilaman ko gipasaligan ug sweldo).

\section{Respondent 3}

He had three reasons for his political crimes: the brutal killing of his brother by the military (Gipatay sa military ang akong igsoon), the abuses of the rich to the poor (Tungod sa pagpanglupig sa mga datu namong mga pobre), and the unjust distribution of land to the landless (Dili makatarunganon nga pang-apod apod sa yuta).

\section{Respondent 4}

His reasons for committing political crimes were martial law, social injustice; and poverty. 


\section{Respondent 5}

Two reasons were cited for his political crimes: poverty (kahirapan) and the imperialistic/feudalistic/capitalistic system of the government ( $\mathrm{gg}$ ang tulo $\mathrm{ka}$ batakang problema-imperyalismo, pyudalismo, burukrata kapitalismo).

\section{Respondent 6}

He cited three reasons for his political crimes: injustice (Inhustisya) and social inequality (Dili makatarunganon ug dili maka-angayon ang katilingban karon).

\section{Respondent 7}

He committed political crime because he was falsely accused (Nadamay lang ug napasanginlan lang). $\mathrm{H}$ then fought against the arresting officers (Misukol sa polis).

\section{Respondent 8}

His reasons for his political crimes were the martial law (Tungod sa Martial law), poverty, and a fight for a genuine freedom (Aron sa tinoud nga kagawasan alang rapud sa mga tao).

\section{Respondent 9}

His only reason for his political crime was for the government to know how unhappy he was about social inequality (Aron mahibaw-an sa gobyerno nga kami wala mahimout sa dili maka-angayon nga katilingban).

\section{Respondent 10}

He had two reasons for his political crimes: poverty for which the rebels promised him a monthly salary (Tungod sa akong ka pobre na dani ko nga mouban sapakig-bisug obos sa ilang saad nga kami anaay binulan nga sweldo) and enticement due to immediate issuance of an armalite by the rebels (Nadani lamang kay giissuehan man dayon ko ug armalite.).

\section{Respondent 11}

He had one reason for his political crime: unjust distribution of land by the DAR to the landless (Dili maka-angayon nga pagpang-apod apod sa yuta sa DAR). 


\section{Respondent 12}

He had two reasons for committing political crime: injustice (Inhustisya) and retaliation for the military officer's physical abuse against him. (Gikulata ko sa mga sundalo ug gusto kung manimalus sa dili maka-angayon nga pag tratar labi na gyud sa akong mga kaubang pobre).

\section{Respondent 13}

He cited two reasons for his political crime: salary promised to him by the rebels and issuance of firearm by the rebels, the latter being the cause of his apprehension ( Nadani ra ko sa ilang gipasalig nga sweldo bulan-bulan ug gitagaan ko ug armas hinungdan sa akong pagkadakpi).

\section{Respondent 14}

His reasons for his political crimes were they were commissioned to fight for social change (Tungod kay kami gitahasan sa pakig bisug alang sa kausaban sa katilingban nga dili makaangayon.) and they saw inequality and wanted their grievances to be heard by the government (Tungod kay sa among grupo nakita nako nga kami pinihig aron kami mahatagan ug tyansa nga madungan sa gobyerno ang among mga yangongo).

\section{Respondent 15}

He committed political crimes for two reasons: unstable government, the rich become richer and the poor become poorer (Nag rebelde ko tungod ra gihapon sa gobyerno walay klaro, kaming mga pobre nisamot ug kapobre ug silang mga dato nisamot ug kadato); and injustices that the government has committed (Tungod sa akong nakita nga inhustisya nga gibuhat sa gobyerno)

Table 3. Summarized Data on Suggestions on How to Prevent and Suppress Political Crimes

\begin{tabular}{|l|c|c|}
\hline \multicolumn{1}{|c|}{ Suggestions } & Frequency & Rank \\
\hline $\begin{array}{l}\text { The government (police and military) should respect the } \\
\text { individual's rights. }\end{array}$ & 3 & 1.5 \\
\hline The government service should be performed well. & 3 & 1.5 \\
\hline The government should govern its people justly. & 2 & 2.5 \\
\hline The government should not be corrupt. & 2 & 2.5 \\
\hline The government (military and police) should not commit abuses. & 2.5 \\
\hline
\end{tabular}




\begin{tabular}{|l|c|c|}
\hline There should be justice and respect for the poor people. & 2 & 2.5 \\
\hline $\begin{array}{l}\text { The government officials should not consider their personal } \\
\text { interests only. }\end{array}$ & 2 & 2.5 \\
\hline $\begin{array}{l}\text { There should be a change in the system of government. } \\
\begin{array}{l}\text { The government should give to the poor what was budgeted for } \\
\text { them. }\end{array}\end{array}$ & 1 & 3.5 \\
\hline The government should strengthen its intelligence force. & 1 & 3.5 \\
\hline The government should consider the issue on poverty. & 1 & 3.5 \\
\hline There should be social justice. & 1 & 3.5 \\
\hline There should be equality and democracy. & & 2.5 \\
\hline
\end{tabular}

Table 3 shows the respondents' suggestions on how to prevent and suppress political crimes in Misamis Oriental. The suggestion that ranked first is for the government (police and military) to respect the individual's rights and for the government to perform it services well. This suggestion is consistent with the earlier finding that social inequality consists of inequality in socio-economic status and in giving respect for human rights. The respondents, therefore, suggested that to prevent and suppress political crimes in Misamis Oriental, individual's human rights should be respected.

\section{Respondent 1}

To prevent and suppress political crimes, he suggested that the government should govern the people justly and rightly (Tarungon sa gobyerno pagdala sa mga tao), that the government should not be corrupt and should give to the poor what is due to them (Dili korakoton ang kuwarta nga gilaan sa mga pobre), and that the government should respect the individual's rights (Ilang ayohon ug dala ang mga tao nga nay pagrespito sa tawhanong katungod).

\section{Respondent 2}

To prevent and suppress political crimes, he suggested that the government should strengthen its intelligence force and not to corrupt the intelligence funds (Dapat ipa igting sa gobyerno ang ilang intelligence ug dili pagakorakoton ang intelligence fund). They should not make abuses so that the rebels will not initiate actions against them (Dili sila mag-abuso aron kami pud dili mohimo ug lihok batok sa ila). 


\section{Respondent 3}

To prevent and suppress political crimes, he suggested that there should be justice for the poor (Kinahanglan adunay hustisya nga maka-angayon para sa among mga pobre); that the government should give more consideration to the issue of poverty and not to focus on their individual interests (Ang gobyerno hatagan ug dakong konsiderasyon ang among kalisod dili lamang maghuna-huna sa ilang tagsa-tagsa ka mga interest); and that the military and the police should not do any abuses and should respect the rights of the poor (Ang polis ug ang $m g a$ sundalo dapat dili mag abosado, mo respetar sa katungod namong mga pobre).

\section{Respondent 4}

To prevent and suppress political crimes, he said that social justice is needed (Para walay magrebelde social justice). The government should exercise equality and democracy (Equality and democracy ang usa sa gikinahanglan).

\section{Respondents 5, 6, 7, 8 and 14}

They had no suggestions on preventing and suppressing political crimes.

\section{Respondent 9}

To prevent and suppress political crimes, he said that when setting a checkpoint, the police or military should not violate the rights of the individuals (Ang ilang paghimo sa checkpoint kinahanglan dili maka supak sa tawhanong katungod).

\section{Respondent 10}

He suggested that to prevent and suppress political crimes, the government officials/employees should perform their respective services well (Tarungon nila ang ilang pagpanerbisyo isip sweldado sa mga tawo).

\section{Respondent 11}

He also suggested that to prevent and suppress political crimes, the government officials/employees should do well in their service to the people. (Magtarong sila sa ilang panirbisyo sa katawhan).

\section{Respondent 12}

To prevent and suppress political crimes, he said that the government should fully understand their reasons for rebellion and that it should not advance its officials' vested interests. 


\section{Respondent 13}

To prevent and suppress political crimes, the government should change and correct its system (Ilang usbon ug ayohon ang hewi nga sestima).

\section{Respondent 15}

He had three suggestions to prevent and suppress political crimes. First, there should be a change in the government systems (Aron mawala ug masugpo kaming mga rebelde, kinahanglan dunay kausaban sa sestima sa pang-gobyerno). Second, the military and the police should not abuse their authority (Ang mga sundalo ug polis kinahanglan dili mag-abusar sa ilang otoridad). Third, they have to be good in their services, respecting the individual's rights (Tarungon nila ang ilang pagserbisyo nga dili makayatak sa tagsa-tagsa ka tawhanong katungod).

\section{CONCLUSIONS}

The political offenders involved in this study are struggling socioeconomically as they were engaged in farming prior to their detention at the Misamis Oriental Provincial Jail and have a big family to rise. They have limited academic exposure that could have prepared them for the realities of life. Their socio-economic struggle has somehow led them to commit political crimes. While they adhere to the principle of equality and justice, they have seen social inequality and injustices committed in Misamis Oriental where they live, hence their commission of political offenses. Social equality may not always be in the socio-economic term but may also be a longing for true, observable and spirit- felt fairness and justice, far beyond the monetary needs of human beings. When one is treated fairly and equally, the temptation to resist or to fight the authorities or the government may become remote or impossible. This finding that social inequality is the major cause of the commission of political crimes implies two things: (1) the longing for socio-economic equality and (2) the longing for respect for an individual's rights. The preceding conclusion is derived because revenge, government abuses and injustices, poverty and social injustice ranked equally as causes of political crimes in Misamis Oriental. These causes are common elements related to respect for an individual's human rights. However, political crimes in Misamis Oriental can be prevented by establishing priority and sustainable programs for poverty alleviation and promotion and protection of human rights. 


\section{RECOMMENDATIONS}

1. Laws and local ordinances that would establish lasting social justice and equality among those who are in the remote areas of Misamis Oriental should be enacted to change their perspective in life and regain their confidence in the government and its system.

2. The local government of Misamis Oriental should seriously address the issue of poverty especially in the hinterlands of Misamis Oriental. Poverty alleviation programs and projects are addressing poverty should be implemented by the local government of Misamis Oriental.

3. The police and military should be held fully accountable for any breach in the operating procedures to rebuild the moral fiber of the society and regain the respect of the citizens for the police and the military.

\section{LITERATURE CITED}

Cullen, F.T.

2006 Criminological Theory: Past to Present: Essential Readings, Roxbury Publishing Company. Retrieved on August 12, 22013 from (http:// www.barnesandnoble.com/w/criminological-theory-francis-t-cullen/11 00038441 ?ean $=9780195389555$ )

Keightley, R.

1993 Political offences and indemnity in South Africa. S. Afr. J. on Hum. Rts.,9,334. Retrieved on October 11, 2013 from (http://heinonline.org/ HOL/Landingpage?handle=hein.journals/soafhr9\&div=\&page=)

People vs. Hernandez, 99 Phil. Reports 155. Retrieved on September 9, 2013 from (http://en.wikipedia.org/wiki/Peolple_v._Hernadez)

Petersen, A. C.

1991 Extradition and the political offense in the suppression of terrorism. Ind. LJ, 67, 767. Retrieved on July 30, 2013 from (http://heinonline.org/ HOL/Page=hein.journals/indana67ddiv $=35 \mathrm{~g}$ sent=)

Philippine Law Journals 395. Retrieved on October 11, 2013 from (http://miriam. com.ph/newsblog/wp-content/uploads/2011/10/IDENTIFYING- 


\section{THE-POLITICAL-OFFENDER.pdf)}

NPA Attacks Del Monte, DOLE (Tempo Newspaper, February 21, 2013 Issue). Retrieved on August 19, 2013 from (http://www.tempo.com. ph/2013/02/npa-attacks-del-monte-dole/\#.UnzuZVOoozc)

RA 6975.

1990 Otherwise known as the "Department of the Interior and Local Government Act of 1990". Retrieved on October 11, 2013 from (http:// www.lawphil.net/statutes/repacts/ra1990/ra_6975_1990.html)

RA 8551.

1998 Otherwise known as the "Philippine National Police Reform and Reorganization Act Retrieved on October 11, 2013 from (http://www. usep.edu.ph/GAD/images/sitedocuments/Laws/National/General\%20 PurposesLaws\%20that\%20Affect\%20Women/republic_act_8551.pdf) 